\author{
TAUFIK IBRAHIM
}

\title{
Islam and Partial Modernization: There Was No Liberation from Medieval Elements
}

\author{
Translation by Anna Amramina
}

DOI: $10.22394 / 2311-3448-2018-5-1-139-153$

Taufik Ibrahim - Institute of Oriental Studies of the Russian Academy of Sciences (Moscow, Russia).nataufik@mail.ru

In his interview Taufik Ibrahim argues that the main problem for Muslims is that the traditional, medieval understanding of religion has not yet been overcome. This traditional understanding is connected with the loss of the initial creative impulse of early Islam, with the so-called closure of the gate of ijtihad. Both the fundamentalists and the reformists typically reference the early Islamic period. But the question is, why do they do so? Is it in order to find ready-made answers or to find the inner sense of this or that statement, to liberate them from historical limits and discover how to realize them in modern life? T. Ibrahim thinks that there is no clash of Western and Islamic civilizations but there are clashes between traditional and modern values within civilizations. His view is that in Muslim countries the modernization of the society without religious reform, as took place in Turkey, cannot protect society from setbacks as long as the traditional understanding of religion remains untouched. And such radical organizations as ISIS exploit this situation. In the reformation of Islam T. Ibrahim underlines the special role of the Islamic periphery, mostly Europe, and also including Russia.

Keywords: Islam, globalization, traditional understanding of religion, reformation, citizenship, humanism.

Originally published in Russian as: Ibrahim, Taufik (2017) "Islam i odnobokaya modernizaciya: Ne proizoshlo osvobozhdenie ot srednevekov'ya” (interview), Gosudarstvo, religiia, tserkov'v Rossii i za rubezhom 35(3): 300-317. 
$2 \gamma$ We all understand, and more so with time, that the Muslim world is going through something. It probably began roughly with the Arab spring. What happens in Muslim countries or with Islam as an ideology or a doctrine, even in connection with Islamic eschatology, appears in the headlines more and more often. In your opinion, what is happening in the Muslim world?

Taufik Ibrahim: Actually, by and large there is nothing special, nothing extraordinary happening in the Islamic world. There are countries, whether we call them developing, or third-world, or something else, that are searching for their own path in the modern world. They are a long way from leading positions, which naturally motivates them to respond in some way, to undertake something. Moreover, this is not only a problem for Muslim countries. Turbulence will linger until we develop a relatively even distribution of wealth on the global scale, until we reach a consensus on fair and equivalent exchange.

Two things are probably actually specific to Muslims. First, there are numerous oil and gas resources in Muslim countries. The role of oil in the global economy is well known. It will remain one of the main factors that will determine outside interest in the Muslim world for many years. The second is Islamic ideology itself, its specificity as a religion. Islam is a religion with an active life philosophy and active opposition to evil. In various regions and countries they might respond differently to unfavorable, negative manifestations of globalization. Muslims are particularly sensitive in this respect.

Personally, I have nothing against globalization itself. Generally speaking, globalization, or universalism, is an overarching tendency that has been present throughout the entire course of human history. Recall Alexander the Great's conquests, for one thing. Christianity, and later Islam, are nothing short of global projects. I see nothing wrong if a culture, considering itself more worthy, wishes to bring its values and ways of life to others. However, these others have the right to resist attempts to impose other values and life standards on them.

I would also like to draw attention to another point. Previously, during Soviet times, the world was bipolar. One force opposed the other. Tendencies toward protest, which are, were and will be always will be out there, mainly accumulated within communism and socialism. Now, it is largely Islam that accumulates these tendencies. 
And yet, it was namely Muslim countries that developed the idea that the reason they were trailing behind the West - Europe and Ameri$c a-$ was that these states drifted from the fundamentals of Islamic religion and only a return to true Islam would allow them to regain leading positions. What do you think, how seriously does this kind of ideology influence what is happening now in the Muslim world?

It is very popular. Moreover, one of the main aspects of critiques of globalism is that globalism is in fact neocolonialism, a continuation of the imperialist expansion of the West.

There is also profound nostalgia (not unlike in Russia) for the glorious past, a deep sense of historical resentment. We built a global empire under the banner of Islam, spread our influence in numerous countries, created a great civilization and a highly developed culture. Thus, the proposition to reinstate the caliphate to return to former glory is a necessary part of this ideology.

Added to this is an attempt to blame everything on others, which is typical in these cases. In particular, European nations are considered responsible for the backwardness of their respective colonies. I will note the following about this. Of course, we should not disregard the negative aspects of colonialism and we cannot help but notice that Europe or the West have not always had the best intentions in their relationships with Muslim countries, to put it mildly. However, this is only half the truth. After all, colonialism itself is not so much a cause as an effect of our historical and civilizational backwardness and decline after the 14th century.

And who, for example, prevented the Ottoman Empire from producing world-class scientists?!

Why do you think it is so?

Because the conservation of religion was occurring, what is conventionally called "closing the gate of ijtihad." This is a term we began using after the fact to describe stagnation and rejection of the creative impulse of the 8th to 13th centuries, the period that corresponds to the Middle Ages in European history. Europe first had the Middle Ages and then the Renaissance, whereas we had the opposite - the Renaissance first and then the Middle Ages. It so happened that we revived 
the classical culture but then it was as if we rejected our own accomplishments. After the 13th century, conservative orthodoxy prevailed. And it was this rule of orthodoxy, not the crusades or the Mongol invasion, that was the main cause of stagnation and the subsequent decline of the Muslim civilization.

Essentially, you are also saying that some distortion of the initial religious impulse led to the fact that Muslim countries began to fall behind. So, how do you differ from those whom you refer to as fundamentalists?

Fundamentalists and reformists happen to share this particular point, in this respect they do not differ from each other. There are conservative Salafists and modernist Salafists. If you criticize historical layers, you should say where to go. "Let's go back to the original Islam!" But what do you want from the original Islam? Some people look for literalness, ready-made recipes that it used to offer. Others look for meaning, the spirit of this or that religious institution. They search for a way to implement this goal in modern circumstances by currently available means, that is, release the institution from a strong attachment to the historical circumstances in which it was formulated. This is where the principal, fundamental difference lies. However, going back to the beginning is a shared value for fundamentalists and reformists. Remember Luther's formula: down with tradition, back to the Bible.

Why do fundamentalists play a leading part among those who call for going back to basics?

There are two reasons for this. The process of transitioning from a medieval to a modern understanding of religion is a very painful one. Who introduced it to Europe? First and foremost, secular authorities. As a rule, secular powers did not allow proponents of the old understanding to pressure innovators. This did not happen in Muslim countries. Secular rulers did not even set the task of the reformation of religion for themselves.

Let us look at Turkey, the country that has progressed furthest along the path toward modernization. You would think that Ataturk brought it closer to Europe by separating the state from religion. But even before Erdogan and his party rose to power, I was arguing that was a dead-end road. A lopsided modernization was implemented, 
which modernized society without reforming religion. There has been no liberation from the Middle Ages (I do not mean "from religion"), from the medieval understanding of religion. That is, even Turkey has not passed this stage.

Or let us take, for example, Sharia law. Apart from wearing hijabs, cutting of hands, and stoning, what does it mean to the general public, in the mass consciousness?! As we are informed, over the entire course of the Ottoman Empire's history there was not a single case of cutting off hands or stoning. Well, what of it? Refraining from enforcing medieval laws, forgetting about them for a while is not enough. There was no ideological liberation from medieval practices, there was no actual religious justification for rejecting them. Which means that if someone like a person from Daesh (ISIS) ${ }^{1}$ comes along and starts to explain to Muslims that they, it turns out, were not "living the Islamic law," he will win. And most of their audience will sincerely repent their past transgressions.

So, the first reason is that the medieval period itself, the medieval understanding of religion has not been overcome, or, to be more precise, no one has touched it. In this regard, it is significant that schools affiliated with Al-Azhar finally abandoned a section of the curriculum about the enslavement of prisoners of war, i.e., of turning men into slaves and women into concubines, just last year. In all likelihood, it was eliminated under pressure from President el-Sisi.

You see, this medieval practice has not been debunked. Yes, legislation in most Muslim countries does not stipulate the death penalty as punishment for adultery, and for many decades people have lived peacefully without it. But if a fundamentalist begins actively promoting it as a true requirement of Islam, most Muslims will likely be willing to listen, because secular regimes in these countries have not established another understanding of religion. Thus, a solid foundation has been preserved almost everywhere for reviving the traditional, medieval understanding of religion. In fact, Daesh is a legitimate offspring of the medieval interpretation of Islam. Its ideologues do not invent anything new, it is all in authoritative books, according to Sharia. It is a different matter that many countries have not used it for a very long time.

Now, to the second reason. Most of these countries had regimes that were authoritarian to varying degrees and that did not tolerate any liberal or democratic opposition. By contrast, they gave the green light to

1. ISIS is illegal in the Russian Federation by the ruling of the Supreme Court of the Russian Federation of February 14, 2003, GKPI \#O3 116, in effect from March 4, 2003. 
religious movements as long as they left the authorities alone in their mosques and preaching. Thus, religious movements had a free hand in spreading their ideology, their own understanding of Islam. As a result, liberal-democratic forces were driven out. As an aside, I will mention that against this backdrop the events in Egypt as a result of the second wave of the revolution came as a complete surprise to everyone, when tens of millions of protesters came out against the so-called Islamic project.

Circling back to your question, these authoritarian regimes are no longer popular in most of these countries. And we are witnessing two alarming phenomena almost everywhere: corruption and population growth. The size of the population is the biggest problem, it is a tragedy for most third-world countries. In contrast, modern technologies require job cuts. The population in Arab states doubles every quarter-century. The situation turns out to be objectively unfavorable for young people, there are no prospects for them. Even an ideal regime would struggle tremendously to meet the needs of a constantly growing populace. What is the solution? The liberal-democratic protest of the population? No. It is easiest to turn to religion. And this is what people do. What else is there?

At the very beginning of the interview, you said that Muslim countries, as other third-world countries, are looking for a path to modernity. You are now saying that the medieval understanding of Islam prevails in these countries. Is there a conflict between the search for a path to modernity and the medieval mindset that you mention?

There are societies based on secular life. There are also Bedouin, tribal societies. In many countries people still live as if by Bedouin standards, with tribal chiefs and hereditary power. They have not moved beyond this. I thought we had overcome this in my native Syria. Alas, we have not. An entire tribe would go back and forth between the side of the opposition and the side of the regime. The Bedouin, or, if you will, traditional organization of society still prevails. It is, of course, fraught everywhere with fundamentalism. It forms a ready-made base for all sorts of counterreformations, and it always will. This is, however, just an add-on to a larger problem.

It is not about who will offer a more acceptable variant of ideology; this is a secondary question if crucial issues are not being dealt with. How do we feed the people? This is the main thing. If we cannot feed the peo- 
ple, then there is a simple solution: to take up arms. Let the entire world pay us jizya (a tax on non-Muslims in a caliphate). Switzerland flourished at the expense of people from other countries who kept their money in Swiss banks. So, we will live off jizya. These easy fixes will always be tempting. We should not oversimplify the problem, reducing it all to the fact that there are dictatorial regimes and medieval mindsets. There are objective issues in the form of massive population growth and shortage of natural resources. It is a huge issue that is not being addressed.

One more clarification. You have discussed two different positions on the role of fundamentalist Islam that tend to clash with each other in Western scholarship. This is, in fact, the debate between Olivier Roy and Gilles Kepel. Is radicalism the essence of Islam or is Islam just another ideology that protesters adopt because there always must be a protest ideology in the world?

In fact, these two positions are not so polar, they are not mutually exclusive. Before talking about the "essence of Islam," we must define which "Islam" we are discussing. Sacred texts themselves are one thing and their interpretations are another. Moreover, interpretations can differ dramatically, and not just from one historical era to another, but within one period as well. As far as radicalism is concerned, Islam as understood by medieval Faqih theologians differs from that of Sufi mystics of the Ibn Arabi school, for example, who developed a pluralistic interpretation of faith that bordered on religious indifference at times. Thus, it would be more appropriate to talk about a dominant interpretation of Islam in this period than about its "essence." The prevailing political doctrine in traditional theology was formed during the time when the rule of force predominated, when everyone fought against everyone else and states were often presented with a dilemma to conquer or be conquered. In these circumstances, of course, only an offensive, militant interpretation of scriptures could prevail. The pacifist, tolerant, pluralistic message of the Quran, which from the reformist-modernist point of view actually reflects the true essence of Quranic ideas, was cast aside.

To a certain extent, this political doctrine now occupies the niche for protest groups that communist and socialist ideas used to occupy. Who was it that organized explosions in Europe back then? What were they called? 
There were all sorts of Red Brigades.

What was their fundamental difference from terrorist acts that are currently performed under pseudo-Islamic slogans? There is nothing specifically religious in this. It is not that difficult for any more or less mass ideology to adopt what we call a radical understanding. It only requires finding forces that are interested in it.

Another factor must be taken into account here. We have advanced considerably in terms of establishing humanist values, but we must not forget that the situation was much more complex in Europe not too long ago. We are now outraged by these Daesh bandits who cut off heads. Do you know what the Europeans did in their colonies? In India, British soldiers committed atrocities against the local population, they raped their wives, murdered their husbands, and forced widows to wear their dead husbands' skulls on their necks as necklaces. British soldiers preserved evidence of this in photographs, they were proud of them. Or what the French did in Algeria - more than a dozen severed heads of leaders of the Algerian resistance were displayed at the $\mathrm{Mu}-$ seum of Natural History in Paris. Or what the Americans did to prisoners of war in Vietnam. Did the Europeans or the Americans think that was barbaric? There is no place for illusions here, fascism is also a brainchild of the same European culture.

As far as I understand, in many Islamic countries the Arab spring raised very high hopes for democratization, development of Islamic approaches to society, and a new, just, different life. And it failed almost everywhere. In some places it ended in a military coup that overthrew a legitimately elected president, in other places it culminated in bloody chaos. Why?

First, I want to emphasize that the very fact of the Arab spring is a very positive event. People grasped that they had a right to a different life and took to the street to demand it. Regardless of the outcome, we must not belittle the significance of this fact. Otherwise we will see no end of experts who sit around arguing about an East where the ideals of democracy and freedom are generally unfamiliar to people.

It seems to me that what happened in Egypt with the second wave of revolution was an extremely important moment. And again, regardless of how it ended or is going to end. It showed that not every reli- 
gious project will be successful. Millions of religious people rose against the Ikhwan project. I used to think that we were doomed to one of two alternatives, authoritarianism or the Islamist project. As it turns out, there is another prospect. This is the second positive moment.

However, the fact that the Arab spring was such a failure everywhere is more of a natural, logical outcome. Why? Because you may offer a fair critique, but that does not equal having a viable alternative to it. Having the power to overturn the existing regime is not enough. You must have a constructive alternative. If you intend to rebuild your shabby house, you must have an alternative place to stay during the alterations and a clear plan for construction. This is exactly what was lacking in the Arab spring. All of this turned out to be unexpected in some way even for relatively organized groups that came to power on the wave of the Arab spring. They were not ready for this opportunity. They had no agenda. This is the source of their weakness, or, to be precise, their predestination to failure.

\section{I have a feeling that this lesson of the Arab} spring has not been learned.

This is the tragedy of the situation. This lesson also has not been learned from such a concurrent phenomenon as Daesh. And what if we succeed in wiping them out in the near future? I am certain that something similar will quietly appear at a different location a decade or so later. For many radicals and jihadists, the failure of the latest attempt does not mean that the entire project is doomed. They are not afraid to die either. On the contrary, they are eager to become shahids.

It should be more of a lesson for those forces that were relatively liberal-democratic at the beginning of the protests. This may also be a lesson for the West, which, in my opinion, took the wrong stand with the opposition, just like it had earlier made a mistake by supporting various authoritarian regimes.

Perhaps more exactly - I hope that these events will not pass unnoticed by the moderate wing of political Islam, though it appears that none of their ideologues yet have a higher mission. We have been asking for a positive alternative for over a century. And yet, in effect they stay within the traditional understanding of religion, which is simply incapable of producing an appropriate, promising, viable project.

Proponents of the reformist modernistic approach, such as myself, have a different understanding of Islam. For us, the Prophet Muham- 
mad laid the foundation, launched the forward motion, and marked certain directions of development. For traditionalist fundamentalists, he is perfection, a pinnacle to aspire to, and all our efforts must be directed toward recreating the order established during the time of the prophet and his closest companions and followers.

We need to overcome the traditional understanding of history of the three Abrahamic religions - Judaism, Christianity, and Islam and move away from the traditional eschatological regressivism, according to which the "Golden Age" is behind us and we are all rushing forward, toward the end of the world. All hope is placed in the Messiah who decides the fate of the world. It is impossible to create a civilization within this paradigm, with such a mindset. We must move from a regressivist paradigm to a progressivist one.

As far as modernization of Muslim societies is concerned, it must be immanent in ideological terms and based on internal resources. It must come from within, and in no case should it be imported. Otherwise it will be short-lived and not very promising.

In addition, we must go through a modernization program. Precisely this aspect is often missing, which is the problem with most third-world countries including Muslim states. When something positive is taken from the European experience, it remains one-sided and disconnected from the underlying foundation, and as such it turns out to be ineffective, "it doesn't work." While in Europe it was hard-won: a high price was paid to establish science by a multitude of martyrs and Galileos.

But this does not mean that we must inevitably traverse the same bloody path that Europe did. We must try, as much as possible, to avoid those sacrifices that were made in Europe in order to establish new understandings of religion. Although, what is happening now in certain Muslim countries resembles the pangs of the birth of a new society.

Muslim migration to the West, to Europe, is not a new phenomenon, but it has now acquired a completely different magnitude. How do you think this will influence the understanding of Islam and of Western society itself? What can we expect from it?

I look at this phenomenon in light of the experience of Russian Islam. In my opinion, in the 19th and early 2oth century Russian Muslims were in the most advanced position of the entire Muslim world in terms of an accurate, correct understanding of Islam. They lived in fundamentally different conditions. Religion and politics were not 
particularly closely tied in the country, and in such circumstances one might conclude, for example, that an alliance between religion and politics or between religion and the state is negative, especially for religion. I believe that migrants, who have more freedom in discussing Islam, will move toward a more accurate understanding of religion than those who live in the citadel of the Muslim world. In this sense, much hope rests on the Islamic periphery. In his time the great Tatar thinker Ismail Gasprinsky said that the Muslims of Russia must stand in the forefront of the entire Islamic world. This position is also promising for European Islam as a whole.

This is one side of the coin. The other side has to do with whether most Muslims will manage to assimilate into a new context and how our modus vivendi will be integrated into a new environment. If it succeeds, it will be good for all. If it fails, it will be a disaster.

You mean, will they be able to fit into this new society?

One of the most complex problems, which has almost never been addressed since the dissolution of the caliphate, is connected to religious justification, the religious legitimacy of the transition from life in a religious society to life in a political and civil society.

Today we live in a state based on geographic or political principles. The main criterion here is citizenship rather than religious or ethnic identity. For example, I am a citizen of Russia, a Muslim, an Arab, someone else is a Russian Orthodox Christian, or a Jew, etc. But as fellow citizens we have the same rights, we are citizens of this country. Everyone must understand that we live in a political state, not a religious one. A different principle of identity is at work here. If we do not recognize this identity, then, for example, a Muslim will consider that any Muslim anywhere is more akin to him than a non-Muslim. We must learn to carry a variety of identities at the same time. Besides religious and ethnic identities, there is a civic identity, and this should be primary, central to all socio-political matters. Unfortunately, we are still far from this awareness.

Speaking about migrants in Europe, I believe people often fight all sorts of artificial battles. For example, about the hijab. If you want people to part with an inaccurate interpretation of religious symbolism which you believe has no place in modern society, if you really want to help people to drop the inaccurate interpretation, you must not choose confrontation. It provokes an escalation of protest. You must not drive yourself and Muslims into an impasse. 
And in general, I think the European project of rationalism and secularism is not entirely justified. Historically it was warranted as a reaction to the medieval understanding of Christianity. In the grand scheme of things, however, this project is not justified and not very promising. As a result, instead of Christianity we have various forms of mysticism, neopaganism, and Satanism, which are simply replacing the role, the niche that used to belong to Christianity. It is not the best alternative. We need to establish a synthesis in which religion takes its proper place, and that will not create discomfort for someone who is both religious and engaged in science. This is the direction in which Europe must move.

For now, I must state that European culture has gone too far in secularization. Sometimes the militancy of its secularists is no less revolting than actions of religious fanatics. As types, I see little difference between them, when people claim: "I can wear whatever I want or even walk around with no clothes, but you have no right to cover your hair"!

What do you see as the causes of the phenomenon known as Islamic terrorism?

All radicals claim that they opt for lesser harm to prevent greater evil. If you remember, in the history of Christian Europe the same sort of motive was in circulation: burn heretics and their children as a mercy to them, for the less they sin on this Earth, the better it will be for them in the other world. Unfortunately, similar arguments work almost everywhere. Take the example of the American nuclear bombing of Japanese cities of Hiroshima and Nagasaki during World War II. Or the use of napalm by those same Americans in Vietnam. We are not always inclined to ponder these phenomena and acknowledge that they are of the same nature.

In this respect, I would like to draw attention to one psychological aspect of our time, the age of technology. If, for example, they broadcast a bombing killing several hundred innocent people, this causes less shock for the audience than, let's say, a show on television in which somebody's finger is cut off.

I have one last question. If we try to sum up the discussion and go back, so to speak, to the beginning - what is going on in the modern world? Is it a clash of civilizations? Is it a global inter-Islamic conflict, between Shia and Sunni Muslims or between traditionalists and reformists? Or is it another process? How do we package it? 
I would not recommend packing it all in one package. Because different processes are happening in the world at the same time. There was a project of secularizing Europe, now a process of desecularizing Europe is going on. There was a project of modernity that was replaced by postmodernity. Globalization advances but there is resistance to it. The Muslim world is also heterogeneous, depending on region and country. We should not think that everything needs to fit into one big scheme. This temptation is counterproductive. Instead, such generalizations must be avoided.

Yes, in some ways there is a clash of civilizations. We just need to specify which civilizations we mean. If specific claims are made about them, the ensuing theory might end up being very questionable. If we mean a clash of two approaches to the role of religion in society, then this understanding is correct. Can it be framed as a civilizational conflict? I do not see anything wrong with that.

Yet currently, when a clash of civilizations is discussed, a very specific meaning is attached to it. It is the clash of Western and Islamic civilizations.

Modernization is a transition to an understanding of society that $\mathrm{Eu}-$ rope developed, and we must give it credit for it. There is a struggle between the old understanding and the new, and it is of course a complex civilizational process. However, it is not happening between human communities, but within each of them.

\section{But do Islamic and Western values clash?}

Not exactly. It is a fact that certain values of the traditional Muslim culture clash with modern values. However, it is not a clash of Islam with the modern world or the West. The traditional understanding of Christianity also clashes with the values of modern Western civilization. Not only the hierarchs of Eastern Orthodoxy, but also those of Catholicism, call modern Western culture satanic.

So, you believe that a civilizational conflict is more of a clash between the old and the new within each civilization than between civilizations? Do I understand your position correctly?

Precisely. Moreover, we must generally be extra careful when promoting these types of global theories on the clash of civilizations, religions, 
denominations, ethnic groups, etc. There is a critical difference between a study of distant historical realities and a study of realities that can serve as the foundation for concrete decisions that are of critical importance for these realities, and not just for them. We must exercise caution and be aware of all the responsibility. It is not just about being politically correct. We are not discussing the history of disease from the distant past. We are giving a prescription, through which the patient may or may not be cured, may survive or die.

Whatever the cultural, religious, ethnic, linguistic, or economic differences between people, we all belong to one humankind. We are all sons and daughters of Adam and Eve, and that means what we are members of one family. We must think about solving global problems together.

Humanist ideals that are the talk of our society must include a deep feeling of mutual respect between people, regardless of who they are, Russians, Arabs, French, or Chinese. . . We are moving in this direction, but we still have not made much progress. In one place people are rolling in money while in another children are dying from starvation. Every single life should be valuable to you. Only then it will be true humanitarianism.

\section{So, Islam is a humanist religion for you?}

Yes, that is my profound conviction. It is not based on my religious identity. I speak as an objective scholar. I have tried to demonstrate this, especially in the book Quranic Humanism, whose first volume came out in 2015.

For me, Islam is a humanist religion, as are other celestial religions. Conflicts arise because of people's misunderstanding of religion. This applies to conflicts between religions, different denominations within one religion, and between religion and science in general. Nature, whose laws are revealed to us by science, is as much a scripture as sacred books, for example, the Quran. These two scriptures cannot contradict each other. If you find a seeming contradiction, it means that you misinterpreted the text of the scripture.

Similarly, religion is love above all else, God's love for us and in return, our love for Him. Love for God should be expressed mainly through love for His creations. If something contradicts this principle, you are misinterpreting the wording of the scripture that comes from God.

However, a crucial fact that I have already mentioned must be considered while reading the Quran, namely: In the Quran, God addresses 
people according to their mentality or the level of their intellectual or social development. The Prophet Muhammad, who acted as a reformer, naturally had to take this into account. That is why in many areas he pursued not what was desired or ideal, but what was viable in that time. Quranic messages directed at all societies and all times are one thing, and messages that were designed for the Bedouins in Arabia in the 7th century are another. Many rationalists and critics of religion make the theoretical and methodological mistake of disregarding specific contexts in which prophets preached.

Do you know what the Prophet Muhammad lamented about when he was departing for the other world? He complained to his wife Aisha that the Kaaba was not built quite correctly, and he wanted to rebuild it but did not dare to do it. The Meccans had just joined Islam and the Prophet feared that such a reconstruction might drive them away from Islam. Listen to what I'm saying: the Prophet was afraid to rebuild the Kaaba, our holiest site, to which we make pilgrimage and which we address five times daily in our prayers, and you want him, for example, to free slaves or give women equal rights in one fell swoop? You cannot ask that of him. He was a reformer, he did what he could but trod carefully. In many areas, the Prophet only marked the general direction for further development. Conservative fundamentalists fail to understand precisely this. They call for a return to the way it was during the time of the Prophet as something complete, perfect, and ideal, without due regard for particular historical circumstances.

If you consider the historical context, you will find a much more rational, intellectual, and humanitarian intent in the Quran. This essence of the Quranic message of Islam must be distinguished from its historically contingent interpretations in theologians' works and the practice of Muslims themselves.

\section{Interview by Irina Starodubrovskaya}

